\title{
Pengembangan Media Berbasis Mind map untuk Meningkatkan Pemahaman Siswa pada Pelajaran Teknik Pengolahan Video
}

\author{
Desy Yanti Cobena ${ }^{1}$, Dwi Maryono ${ }^{1}$, Basori $^{1}$ \\ ${ }^{1}$ Program Studi Pendidikan Teknik Informatika dan Komputer Fakultas Keguruan dan Ilmu Pendidikan Universitas Sebelas Maret \\ E-mail: basori@staff.uns.ac.id
}

\begin{abstract}
Learning achievement determined by acceptance of students' understanding of learning material. Therefore, a media that makes it easy for students to receive learning materials is needed. This research aims to create an interactive learning media with mind map concept in Video Processing subject. Method used in this research was research and development with 5 steps, (1) problem and potency analysis, (2) data collection, (3) product design, (4) design validation, and (5) design improvement. Media's advisability, which had developed, in percentage are $89 \%$ from media expert, $92 \%$ from material expert, $85 \%$ by users (limited) and $87 \%$ from users (expanded). It can be concluded that the design of learning media is "very appropriate". The benefits of the learning media are: (1) interactive and fun, (2) equipped with videos tutorial, (3) equipped with exercises which able to scored and able to see the correct answers.
\end{abstract}

Keywords: development, learning media, mind map, video processing subject, vocational school

\begin{abstract}
ABSTRAK
Keberhasilan pembelajaran ditentukan oleh seberapa tingkat penerimaan pemahaman siswa terhadap materi pembelajaran. Oleh karena itu perlu ada media yang memudahkan siswa dalam menerima materi pembelajaran. Penelitian ini bertujuan untuk menghasilkan sebuah media pembelajaran interaktif dengan konsep mind map pada mata pelajaran Teknik Pengolahan Video. Metode penelitian yang digunakan adalah penelitian dan pengembangan dengan 5 tahapan yang dilalui yaitu, 1) analisis potensi dan masalah, 2) pengumpulan data, 3) desain produk 4) validasi ahli, dan 5) revisi desain. Media yang dikembangkan mendapat persentase kelayakan sebesar $89 \%$ dari ahli media, $92 \%$ dari ahli materi, $85 \%$ dari pengguna skala kecil (terbatas), dan $87 \%$ dari pengguna skala besar (diperluas). Dapat disimpulkan bahwa media yang dikembangkan "sangat layak". Media pembelajaran yang dikembangkan memiliki kelebihan yaitu interaktif dan menyenangkan, menggunakan video tutorial dengan materi yang sesuai kebutuhan, dan terdapat evaluasi di setiap materi dengan umpan balik berupa nilai.
\end{abstract}

Kata kunci: pengembangan, media pembelajaran, mind map, teknik pengolahan video, SMK

\section{PENDAHULUAN}

Kurikulum 2013 merupakan pengembangan dari Kurikulum Tingkat Satuan Pendidikan (KTSP). Kurikulum 2013 tidak hanya berbasis kompetensi, tetapi juga berbasis karakter. Siswa diharapkan dapat mengembangkan kemampuan yang dimilikinya, dan dapat bersaing dalam dunia kerja [1]. Kurikulum ini memuat aspek spiritual, sosial, pengetahuan dan kemampuan sehingga diharapkan siswa menguasai materi yang diajarkan, memiliki kemampuan dan juga memiliki karakter yang baik. Selain itu, dalam praktiknya, siswa diharapkan dapat mandiri dan tidak bergantung pada gurunya (teacher centered). Disinilah pendidik memiliki peran mengembangkan situasi belajar yang memungkinkan setiap siswa bekerja dengan kemampuan masing-masing pada setiap pelajaran, dan mengusahakan keterlibatan peserta didik dalam berbagai kegiatan pembelajaran. Demi mencapai tujuan tersebut, pendidik dapat menggunakan metode dan media pembelajaran yang bervariasi, dan memanfaatkan berbagai fasilitas dan sumber 
belajar yang ada [2]. Dengan demikian dapat dikatakan, sumber belajar menjadi salah satu faktor yang mempengaruhi keberhasilan kegiatan belajar mengajar.

Mata pelajaran teknik pengolahan video adalah salah satu mata pelajaran kompetensi keahlian Multimedia di Sekolah Menengah Kejuruan (SMK). Kegiatan belajar mengajar dilakukan 2 jam pertemuan dalam satu minggu, dengan jumlah kegiatan praktik lebih banyak dibanding belajar teori. Aplikasi yang umum digunakan, termasuk di SMK Negeri 3 Surakarta, adalah aplikasi pengolah video Adobe Premier dan Adobe After Effect. Kedua aplikasi ini memiliki fungsi yang berbeda namun tetap saling berkaitan.

Berdasarkan hasil observasi dalam mata pelajaran teknik pengolahan video di SMK Negeri 3 Surakarta, kesulitan guru adalah banyaknya materi yang harus diberikan, sementara waktu yang disediakan untuk satu mata pelajaran terbatas. Selain itu, teknik pengolahan video membutuhkan banyak waktu untuk melakukan praktik. Jika guru hanya mengandalkan mengajar dalam jam pertemuan kegiatan belajar mengajar, maka materi yang diberikan terbatas dan mengakibatkan hasil akhir kegiatan belajar mengajar yang tidak maksimal.

Kesulitan lainnya terkait sumber belajar, siswa cenderung bergantung pada penjelasan guru saat kegiatan belajar mengajar berlangsung karena belum tersedianya sumber belajar yang sesuai. Padahal untuk memahami penjelasan guru, setiap siswa membutuhkan waktu yang berbeda-beda, ada yang cepat paham, ada yang perlu waktu lebih banyak, atau perlu pengulangan. Guru mengalami kesulitan jika harus membimbing setiap siswa secara personal.

Disisi lain, siswa kesulitan dalam mengkonstruk materi, sehingga daya tangkapnya rendah. Perlu adanya media yang memudahkan daya serap siswa atau pemahaman siswa terhadap materi pembelajaran. Disinilah terjadi kesenjangan (gap) antara tingkat pemahaman siswa dengan usaha yang telah dilakukan guru dalam mengajar. Terjadi pembelajaran yang tidak efisien. Beberapa alasan di atas, menjadi potensi dikembangkannya sebuah media pembelajaran pada mata pelajaran teknik pengolahan video. Media pembelajaran yang dikembangkan menolong siswa untuk belajar secara mandiri dan guru berperan fasilitator. Media pembelajaran juga menolong siswa memahami materi dan juga menyediakan video tutorial yang sesuai dengan indikator ketercapaian yang tertulis dalam silabus. Saat ini banyak siswa merasakan kesulitan dalam memahami materi jika tidak ada media yang memberikan bantuan untuk mengkonstruksi materi agar dapat lebih faham antar materi. Penggunaan mind map dalam penyajian materi di media ini merupakan salah satu cara yang dapat menolong siswa memahami penggunaan dan hubungan antar bagian dari menu, panel, properti dan sub-sub bagian lainnya dari aplikasi. Beberapa kelebihan mind map yaitu untuk meringkas informasi, menyajikan informasi dengan memperlihatkan keseluruhan struktur; memudahkan dalam mempelajari, menguasai, dan memanggil kembali memori; menjadikan pembelajaran yang bermakna dan tidak hanya bersifat menghafal [3].

Tujuan penelitian ini adalah mengetahui pembuatan pengembangan media pembelajaran interaktif dengan konsep mind map dan kelayakan media yang telah dibuat berdasarkan penilaian ahli dan pengguna. Penelitian ini diharapkan bermanfaat menambah kajian studi pendidikan dan menghasilkan media pembelajaran yang dapat digunakan. Kebaruan dalam pengembangan ini adalah terwujudnya sebuah media interaktif yang tidak hanya sekedar menampilkan tayangan materi, tetapi dikemas agar dapat memberikan pemahaman siswa lebih baik dengan basis mind map.

\section{METODE}

Metode penelitian yang digunakan adalah metode penelitian dan pengembangan atau biasa dikenal dengan Research \& Development (R\&D). Sedangkan yang digunakan adalah R\&D yang dikembangkan Sugiyono [4]. Dari 10 tahap yang ada, pada penelitian ini hanya 
menggunakan dari lima tahap yaitu analisis potensi dan masalah, pengumpulan informasi, desain produk, validasi desain dan desain teruji. Gambar 1 menunjukkan lima langkah R\&D yang dilakukan. Hal ini dilakukan mengingat keterbatasan biaya dan waktu penelitian.

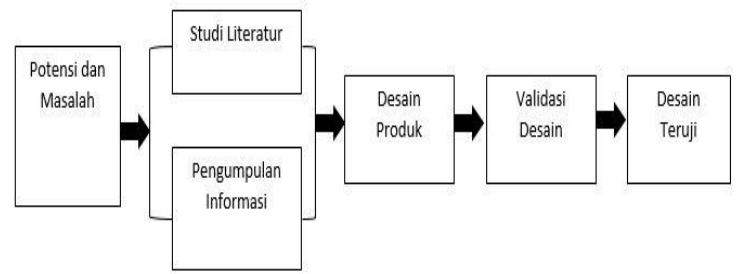

Gambar 1. Bagan R\&D lima langkah

Potensi dan masalah ditemukan saat melakukan observasi kegiatan belajar mengajar dan saat mewawancarai guru pengampu mata pelajaran dan beberapa perwakilan siswa. Setelah analisis potensi dan masalah, dilakukan tahap pengumpulan data. Pada tahap ini, dilakukan pengumpulan penelitian-penelitian yang relevan, buku-buku, silabus dan materi teknik pengolahan video. Pengembangan program media pembelajaran melalui langkah berikut: (1) menganalisis kebutuhan dan karateristik siswa; (2) merumuskan tujuan instruksional dengan operasional dan khas; (3) merumuskan butir-butir materi secara terperinci yang mendukung tercapainya tujuan; (4) mengembangkan alat pengukur keberhasilan; (5) menulis naskah media; dan (6) mengadakan tes dan revisi [5].

Untuk pengembangan sebuah multimedia interaktif dalam pembelajaran, perlu dilakukan analisis kebutuhan [6]. Analisis kebutuhan fungsional bertujuan untuk mengetahui fungsi dari media pembelajaran interaktif yang dikembangkan. Analisis kebutuhan non fungsional bertujuan mengetahui kebutuhan perangkat keras dan perangkat lunak yang digunakan dalam penelitian dan pengembangan. Pengumpulan data dilakukan melalui wawancara dan observasi.

Berdasarkan hasil dari analisis potensi dan masalah serta pengumpulan data, maka dibuat sebuah rancangan media pembelajaran. Langkah perancangan dibagi menjadi beberapa langkah sesuai prosedur pengembangan program multimedia pembelajaran yang interaktif yaitu: membuat flowchart (diagram alir), menyusun materi (storyboard), pembuatan desain antarmuka (mengumpulkan bahan-bahan berupa teks, gambar, animasi, video, audio), implementasi desain grafis (termasuk didalamnya pemrograman, mengorganisasikan seluruh bahan, dan finishing) [6].

Tahap validasi dilakukan setelah rancangan produk telah dibuat. Tahap validasi adalah tahap menilai rancangan media dengan melibatkan pakar atau tenaga ahli yang sudah berpengalaman untuk menilai media. Validasi dalam penelitian ini melibatkan seorang ahli media untuk menilai media yang dikembangkan, ahli materi untuk menilai materi teknik pengolahan video yang disajikan, dan pengguna untuk menilai media pembelajaran dari aspek media dan materi. Tahap validasi dengan pengguna, dilakukan dua kali validasi yaitu validasi pengguna (terbatas) dengan melibatkan guru dan beberapa siswa sebagai perwakilan, dan validasi pengguna (diperluas) dengan melibatkan guru dan seluruh siswa dalam satu kelas. Validasi menggunakan instrumen berupa angket dengan skala penilaian 1-5 untuk mendapat data kuantitatif, dan lembar untuk memberikan kritik dan saran untuk mendapat data kualitatif. Sebelum validasi, instrumen perlu divalidasi oleh ahli media dan materi. Adapun kriteria validasi mengambil pengkategorian menurut Riduwan.

Tabel 1. Persentase Kriteria Kelayakan Media Pembelajaran [7]

\begin{tabular}{cc}
\hline Kriteria Penilaian & Persentase \\
\hline Sangat Layak & $81 \%-100 \%$ \\
Layak & $61 \%-80 \%$ \\
Kurang Layak & $41 \%-60 \%$ \\
Tidak Layak & $21 \%-40 \%$ \\
Sangat Tidak Layak & $0 \%-20 \%$ \\
\hline
\end{tabular}

Revisi Desain dilakukan secara bertahap setelah validasi. Hal-hal yang perlu diperbaiki pada rancangan media pembelajaran diketahui dari hasil penilaian saat validasi desain. Perbaikan pertama dilakukan setelah validasi 
oleh ahli media dan ahli materi. Perbaikan kedua dilakukan setelah validasi oleh pengguna (terbatas). Perbaikan terakhir dilakukan hanya jika setelah validasi dengan pengguna (diperluas) masih terdapat hal-hal yang perlu diperbaiki.

\section{HASIL DAN PEMBAHASAN}

Hasil dari penelitian dan pengembangan media pembelajaran yang dilakukan adalah sebuah rancangan media pembelajaran yang telah dinilai oleh ahli dan pengguna, dan telah mengalami perbaikan. Observasi pada kegiatan belajar mengajar teknik pengolahan video merupakan dasar untuk melakukan analisis potensi dan masalah. Hasil tersebut adalah: (1) jumlah materi yang dipelajari dalam satu tahun sangat luas, (2) metode penyampaian materi berupa ceramah dan praktik, (3) sumber belajar yang digunakan belum ada, (4) pada saat praktik, karena tertinggal siswa seringkali menanyakan pertanyaan yang relatif sama. Hasil wawancara dengan guru dan siswa adalah: (1) guru menggunakan video tutorial yang didapat dari internet sebagai sumber belajar dengan kelemahan isi materi video kurang sesuai dengan silabus; dan (2) siswa merasa kesulitan karena tidak memiliki sumber belajar seperti buku, atau e-book, yang berisi penjelasan materi.

Hasil pengumpulan informasi mendukung dilakukannya pengembangan media pembelajaran dengan konsep mind map, disertai dengan video tutorial, dan adanya evaluasi. Kemudian kebutuhan dari media pembelajaran yang dikembangkan yaitu: (1) dilengkapi materi sesuai dengan kompetensi dasar (KD) kurikulum 2013 mata pelajaran teknik pengolahan video; (2) penyajian materi menolong siswa memahami materi; (3) dilengkapi video tutorial; (4) dilengkapi dengan kuis atau soal latihan dengan umpan balik berupa nilai; dan (5) menarik dan menyenangkan.

Perancangan produk dalam penelitian dan pengembangan ini dilakukan berdasarkan hasil analisis potensi dan masalah serta hasil pengumpulan data. Hasil dari setiap langkah yang dilakukan dalam perancangan media pembelajaran dijelaskan sebagai berikut.

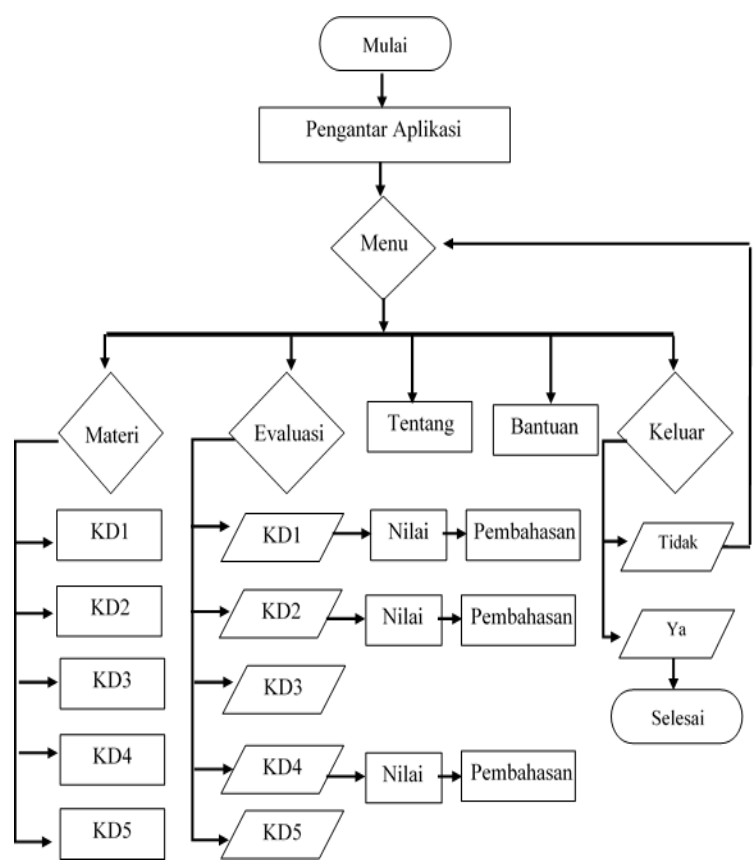

Gambar 2. Diagram Alir Media Pembelajaran

Langkah pertama dalam desain produk adalah merancang diagram alir (flowchart). Diagram alir menggambarkan secara menyeluruh mengenai alur dari media yang digunakan sebagai pegangan dalam membuat media [6]. Diagram alir dibuat sesuai dengan analisis kebutuhan fungsional. Hasil rancangan dapat dilihat pada Gambar 2.

Setelah diagram alir dibuat, langkah selanjutnya adalah menyusun materi dan evaluasi. Penyajian materi dan evaluasi disusun berdasarkan kompetensi dasar yang tertulis dalam silabus [8]. Kompetensi inti (KI) semua mata pelajaran ada 4, yaitu KI 1 tentang sikap spiritual, KI 2 tentang sikap sosial, KI 3 tentang pengetahuan, KI 4 tentang keterampilan. Setiap KI memiliki beberapa kompetensi dasar (KD). Mata pelajaran teknik pengolahan video diharapkan dapat mencapai 12 kompetensi dasar pada KD 3 dan 4 dalam satu tahun ajaran. Namun pengembangan dalam media pembelajaran ini meliputi 5 kompetensi dasar yang diperkirakan menjadi materi pada semester ganjil. Kelima kompetensi dasar dapat dilihat pada Tabel 1 . 
Tabel 1. Kompetensi Dasar Mata Pelajaran Teknik Pengolahan Video

\begin{tabular}{lll}
\hline KI KD & \multicolumn{1}{c}{ Kompetensi Dasar } \\
\hline 1 & 1.1 & $\begin{array}{l}\text { Memahami nilai-nilai keimanan dengan } \\
\text { menyadari hubungan keteraturan dan } \\
\text { kompleksitas alam dan jagad raya } \\
\text { terhadap kebesaran Tuhan yang }\end{array}$ \\
& menciptakannya \\
1.2 & $\begin{array}{l}\text { Mendeskripsikan kebesaran Tuhan yang } \\
\text { menciptakan berbagai sumber energi di } \\
\end{array}$ \\
& alam. \\
1.3 Mengamalkan nilai-nilai keimanan sesuai \\
dengan ajaran agama dalam kehidupan \\
sehari-hari
\end{tabular}

2 2.1 Menunjukkan perilaku ilmiah (memiliki rasa ingin tahu; objektif; jujur; teliti; cermat; tekun; hati-hati; bertanggung jawab; terbuka; kritis; kreatif; inovatif dan peduli lingkungan) dalam aktivitas sehari-hari sebagai wujud implementasi sikap dalam melakukan percobaan dan berdiskusi

2.2 Menghargai kerja individu dan kelompok dalam aktivitas sehari-hari sebagai wujud implementasi melaksanakan percobaan dan melaporkan hasil percobaan

33.1 Memahami pelbagai format video

3.2 Memahami pengoperasian perangkat lunak pengolahan video

3.3 Memahami manipulasi video dengan menggunakan fistur efek perangkat lunak pengolah video

3.4 Memahami pengolahan audio untuk dipadukan dengan video

3.5 Memahami pengolahan teks untuk dipadukan dengan video

44.1 Menyajikan pelbagai format video

4.2 Mengolah pelbagai format video dengan bantuan perangkat lunak pengolahan video

4.3 Menyajikan hasil manipulasi video dengan menggunakan fitur efek perangkat lunak pengolah video

4.4 Mengolah audio untuk dipadukan dengan video

4.5 Mengolah teks untuk dipadukan dengan video

Setiap pertemuan, guru perlu membuat Rancangan Pelaksanaan Pembelajaran (RPP). Setiap RPP harus melibatkan satu poin dari masing-masing kompetensi dasar pada KD 1 dan 2. Sementara pada kompetensi dasar 3 dan 4 , poin yang dipilih bernomor sama. Di dalam media pembelajaran terdiri dari materi dan evaluasi. Penyajian materi dan evaluasi dikelompokkan berdasarkan poin pada KD 3 dan 4. Penyajian materi diawali dengan menjelaskan kompetensi dasar yang akan dicapai. Halaman selanjutnya, materi disajikan dengan konsep mind map. Langkah pembuatan mind map yaitu: (1) menulis gagasan utama di tengah-tengah kertas; (2) menambahkan cabang dari gagasan utama dengan jumlah cabang yang bervariasi; dan warna yang berbeda untuk setiap cabang; (3) menuliskan kata kunci atau frase pada tiap cabang untuk menyampaikan inti sebuah gagasan dan memicu ingatan anda; dan (4) menambahkan simbol dan ilustrasi untuk memudahkan dalam mengingat.

Penyajian mind map dilengkapi dengan link pada cabang yang akan mengarah pada halaman video tutorial atau memunculkan teks penjelasan. Terdapat 14 video tutorial dalam media pembelajaran. Langkah pembuatan video tutorial yaitu: (1) menentukan isi materi pada video dan menentukan alokasi waktu; (2) merekam praktik pengolahan video menggunakan aplikasi khusus; (3) memasukkan ke dalam aplikasi editing video, menambahkan dengan judul video tutorial dan penutup; (4) merekam audio secara terpisah jika kualitas audio masih kurang baik, kemudian menggabungkan audio dengan video pada saat melakukan edit; (5) menambahkan teks pada bagian yang diperlukan; dan (6) melakukan render video.

Evaluasi dilakukan setelah siswa mempelajari materi. Penyajian evaluasi dalam media ini memiliki dua bentuk evaluasi, yaitu pilihan ganda yang diterapkan pada KD 1,2, dan 4 dan penugasan proyek yang diterapkan pada KD 3 dan 5. Evaluasi pilihan ganda bertujuan menilai tingkat pemahaman siswa. Setelah jawaban dimasukkan, pengguna mendapat umpan balik berupa nilai, dan dapat melihat pembahasan soal. Sementara dalam penugasan proyek, siswa ditugaskan membuat video seperti 
contoh video yang tersedia atau seperti syaratsyarat yang ditampilkan.

Setelah menyusun materi dan evaluasi, kemudian membuat desain antar muka yang langkah-langkahnya terdiri dari merancang tata letak halaman, mengumpulkan atau merancang sendiri teks, gambar, animasi, video, audio, dan tombol. Hasil yang didapat baik dari pengumpulan maupun perancangan, disusun berdasarkan rancangan tata letak halaman dan rancangan penyusunan materi dan evaluasi. Semua disusun dalam aplikasi Adobe Flash termasuk menulis kode program agar media pembelajaran berjalan sesuai dengan fungsi yang diharapkan.

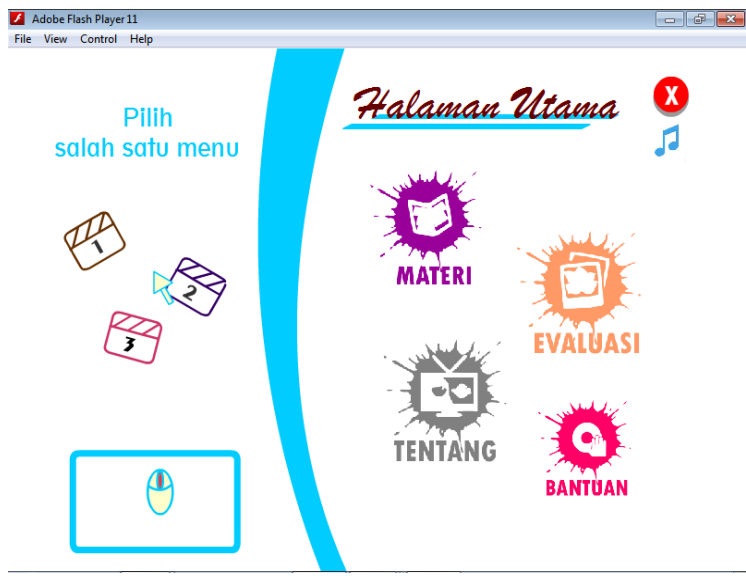

Gambar 3. Tampilan Depan Media Pembelajaran

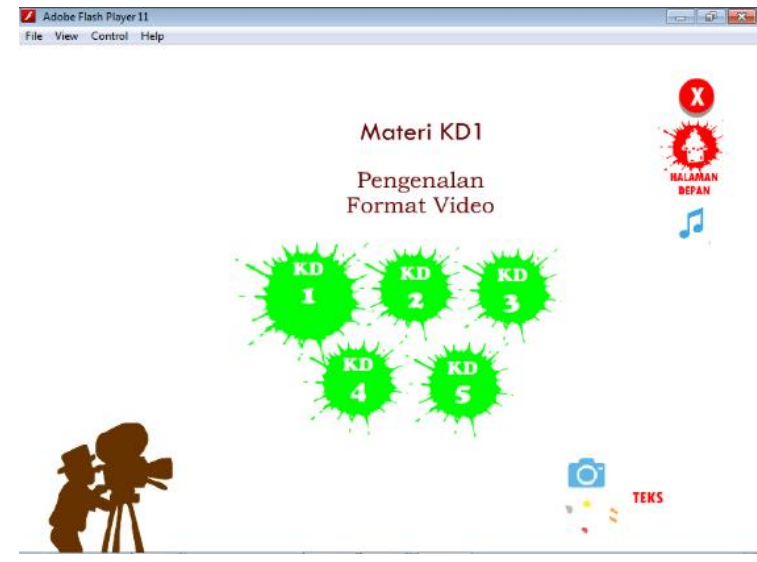

Gambar 4. Tampilan Menu Materi

Gambar 3, Gambar 4, Gambar 5, dan Gambar 6 merupakan tampilan dari media yang dikembangkan. Pengembangan media pembelajaran menggunakan satu unit PC 64 bit dengan RAM 4GB dilengkapi Harddisk space 10
GB dan alat perekam. Perangkat lunak yang digunakan yaitu: sistem operasi Windows 7, aplikasi pengembang Adobe Flash Profesional CS6, aplikasi pendukung video tutorial Adobe After Effect CS6, Camtasia 8, Adobe Audition 1.5, Format Factory, dan pengolah gambar Corel Draw X4.

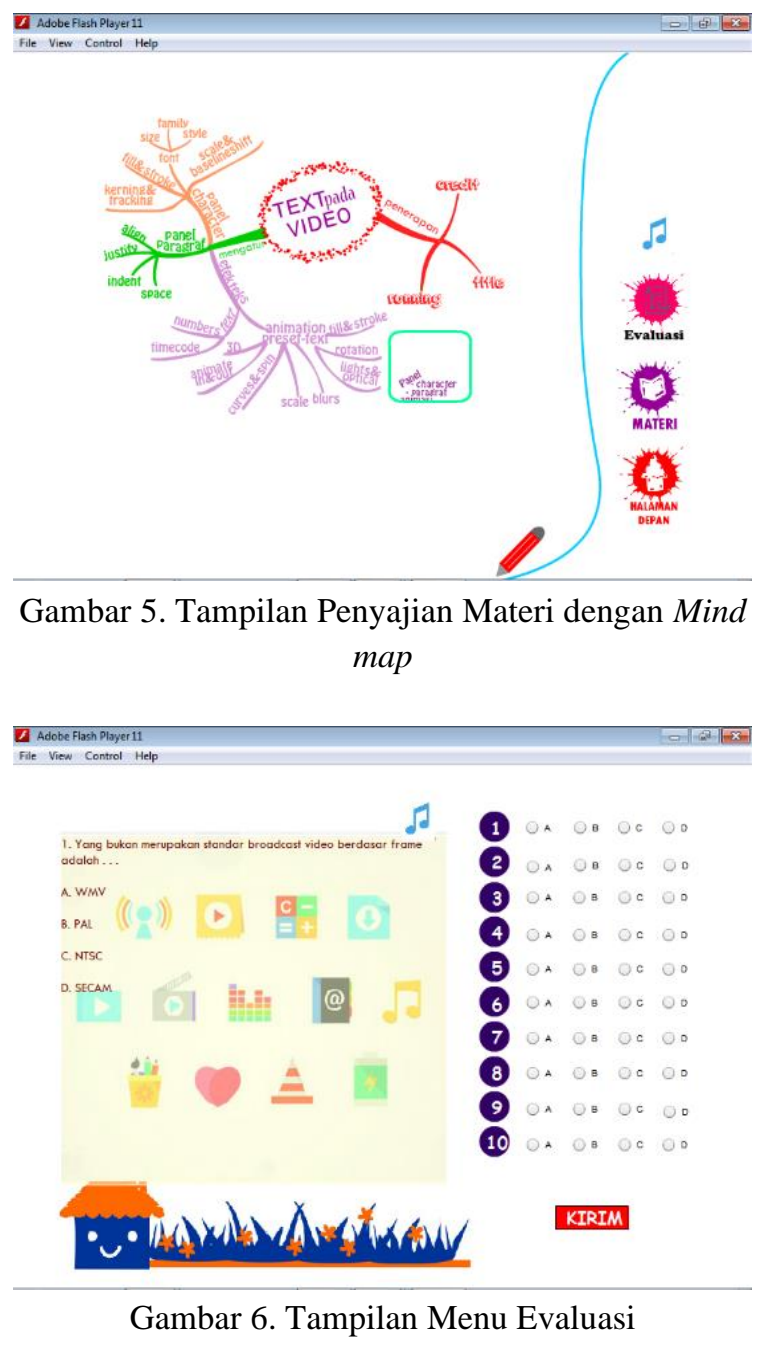

Setelah perancangan media, kemudian dilakukan validasi oleh ahli media, ahli materi dan pengguna. Instrumen yang digunakan berupa angket dan lembar saran dan kritik. Validasi media memiliki tujuan menilai kelayakan media pembelajaran. Penilaian pada pemilihan teks, grafis, suara, navigasi dan kualitasnya dikelompokkan dalam aspek komunikasi visual. Kemudian penilaian petunjuk penggunaan dan kemudahan menggunakan media dikelompokkan dalam aspek rekayasa perangkat lunak. 
Hasil penilaian dari ahli media persentase sebesar $100 \%$ pada aspek rekayasa perangkat lunak dan persentase sebesar $80 \%$ pada aspek komunikasi visual dengan penilaian terendah terletak pada sub aspek grafis dan sub aspek teks. Masukan yang diberikan oleh ahli media yaitu: (1) menambah tampilan loading bar; (2) menggunakan movie clip yang sesuai dengan tema pengolahan video agar lebih menarik; dan (3) menambahkan keterangan pada tombol di halaman Menu Materi dan Menu Evaluasi.

Validasi materi memiliki tujuan menilai materi mata pelajaran teknik pengolahan video yang disajikan dalam media. Penilaian isi materi dan evaluasi dan kesesuaian dengan kompetensi yang diharapkan dikelompokkan dalam aspek substansi materi. Penilaian peyajian materi, penggunaan bahasa dan ilustrasi, penyajian soal evaluasi dikelompokkan dalam aspek pembelajaran.

Hasil penilaian dari ahli materi yaitu persentase sebesar $95 \%$ pada aspek pembelajaran dan persentase sebesar $90 \%$ pada aspek substansi materi dengan penilaian terendah pada sub aspek kualitas materi. Masukan dari aspek materi adalah: (1) menyajikan mind map materi dengan animasi; (2) menambah lengkap teks penjelasan pada video tutorial; (3) menambah keterangan pada Halaman Tentang mengenai aplikasi yang dibahas adalah Aplikasi Adobe After Effect CS6; dan (4) menambahkan halaman pembahasan pada evaluasi. Hasil validasi dengan para ahli menjadi bahan perbaikan dalam tahap revisi desain.

Validasi media pembelajaran oleh pengguna (terbatas) diwakili oleh guru pengampu mata pelajaran dan 3 perwakilan siswa. Validasi pengguna (terbatas) dan (diperluas) memiliki tujuan menilai media pembelajaran dari kemudahan penggunaan media dan materi teknik pengolahan video. Aspek yang dinilai adalah aspek rekayasa perangkat lunak, komunikasi visual dan subtansi materi.

Hasil penilaian dari pengguna (terbatas) adalah $89 \%$ (sangat layak) pada aspek perangkat lunak, persentase $83 \%$ (sangat layak) pada aspek substansi materi dan $83 \%$ (sangat layak) pada aspek komunikasi. Penilaian terendah pada aspek substansi materi ada pada sub aspek kualitas audio dan evaluasi/penutup. Sementara penilaian terendah pada aspek komunikasi visual ada pada sub aspek kualitas suara. Kritik dan saran yang diterima adalah: (1) peletakan keterangan teks menggangu; (2) penyajian evaluasi kurang menarik; (3) mind map membingungkan; (4) tombol audio masih error.

Setelah melakukan perbaikan, kemudian kembali diuji oleh pengguna (diperluas) dengan jumlah pengguna yang lebih banyak, yaitu guru dan siswa satu kelas. Validasi mendapat persentase $90 \%$ (sangat layak) dari aspek perangkat lunak, $85 \%$ dari aspek substansi materi dan $86 \%$ (sangat layak) dari komunikasi visual. Kritik dan saran yang diterima: (1) kombinasi warna kurang sesuai; (2) peta pemikiran beberapa membingungkan; (3) memperjelas font dan gambar; (4) memperbaiki beberapa tombol navigasi yang belum sesuai fungsinya; dan (5) memperbaiki penghitungan nilai evaluasi KD 3.2 dan 4.2 karena belum tepat.

Dengan terwujudnya media berbasis mind map ini, harapan implementasinya adalah sesuai dengan penelitian-penelitian sebelumnya yang menyatakan bahwa media berbasis mind map akan meningkatkan pemahaman [9]-[12]. Disisi lain, mind map juga memberikan motivasi dan ketertarikan siswa untuk belajar [13]. Oleh karena itu perlu dilakukan ujicoba terhadap media ini.

\section{SIMPULAN}

Berdasarkan hasil penilaian terhadap media yang dikembangkan, diperoleh $89 \%$ sangat layak dari ahli media, 92\% layak dari ahli materi, $85 \%$ sangat layak dari pengguna terbatas dan $87 \%$ sangat layak dari pengguna diperluas. Dapat disimpulkan bahwa media pembelajaran interaktif yang telah dikembangkan "sangat layak". Pengembangan media pembelajaran memberi implikasi sebagai berikut: (1) menjadi sebuah sumber belajar untuk membantu siswa; 
(2) membantu guru ketika mata pelajaran Teknik Pengolahan Video; (3) memotivasi siswa menerapkan penggunaan mind map sebagai salah satu cara belajar yang efektif; dan (4) penggunaan waktu dan tenaga serta sumber daya yang lebih efektif dan efisien.

Saran untuk pengembangan media pembelajaran selanjutnya adalah: (1) menyajikan materi dengan konsep mind map atau konsep lainnya yang lebih baik dan mudah dipahami; (2) membuat video tutorial dengan kualitas gambar dan audio yang lebih baik; dan (3) melakukan pengamatan untuk menilai respon pengguna secara alami saat menggunakan media dengan instrumen. Dalam mengembangkan media pembelajaran juga memperhatikan kemampuan hardware dan software yang dimiliki agar dalam pengembangan dapat berjalan maksimal.

\section{DAFTAR PUSTAKA}

[1] M. N. Dwiastuti, A. Efendi, and Basori, "Pengembangan Media Pembelajaran Interaktif Pada Mata Kuliah Teknik Animasi 3 Dimensi Di PTIK Uns Dengan Menggunakan Java Netbeans," in Prosiding Seminar Nasional UNS Vocational Day, 2018, pp. 261-266.

[2] Mulyasa, Pengembangan dan Implementasi Kurikulum 2013. Bandung: PT Remaja Rosdakarya, 2014.

[3] T. K. Tee, M. N. A. Azman, S. Mohamed, M. Muhammad, M. M. Mohamad, J. M. Yunos, M. H. Yee, and W. Othman, "Buzan Mind Mapping : An Efficient Technique for Note-Taking," Int. J. Soc. Hum. Sci. Eng. Vol8, vol. 8, no. 1, pp. 28 31,2014
[4] Sugiyono, Metode Penelitian Pendidikan (Pendekatan Kuantitatif, Kualitatif, dan R\&D). Bandung: Alfabeta, 2014.

[5] H. Musfiqon, Pengembangan Media Dan Sumber Belajar. Jakarta: Prestasi Pustaka, 2012.

[6] D. Darmawan, Teknologi Pembelajaran, 2nd ed. Bandung: PT. Remaja Rosdakarya, 2011.

[7] Riduwan, Skala Pengukuran Variabel-variabel Penelitian. Bandung: Alfabeta, 2009.

[8] L. Astuti, "Pengembangan Media Pembelajaran Interaktif dengan Menggunakan Adobe Flash CS3 untuk Memfasilitasi Kemampuan Pemecahan Masalah pada Pembelajaran Matematika Kelas VIII," Universitas Islam Negeri Sunan Kalijaga, 2012.

[9] E. Merchie and H. Van Keer, "Mind mapping as a meta-learning strategy: Stimulating preadolescents ' text-learning strategies and performance?," Contemp. Educ. Psychol., vol. 46, pp. 128-147, 2016.

[10] T. Wu and A. Chen, "Computers \& Education Combining e-books with mind mapping in a reciprocal teaching strategy for a classical Chinese course," Comput. Educ., vol. 116, pp. 64-80, 2018.

[11] Y. Liu, Y. Tong, and Y. Yang, "The Application of Mind Mapping into College Computer The Application of Mind Mapping into College Computer Programming Teaching Programming Teaching," Procedia Comput. Sci., vol. 129, pp. 66-70, 2018.

[12]P. Utami, G. P. Cikarge, M. E. Ismail, and S. Hashim, "Teaching Aids in Digital Electronics Practice through Integrating 21st Century Learning Skills using a conceptual approach," in Journal of Physics: Conf. Series, 2018, pp. 1-9.

[13] Q. Fu, C. Lin, G. Hwang, and L. Zhang, "Computers \& Education Impacts of a mind mapping-based contextual gaming approach on EFL students' writing performance, learning perceptions and generative uses in an English course," Comput. Educ., vol. 137, no. April, pp. 59-77, 2019. 